\title{
New Eocene South American native ungulates from the Quebrada de los Colorados Formation at Los Cardones National Park, Argentina
}

\author{
Mercedes Fernández, Ana N. Zimicz, Mariano Bond, Laura Chornogubsky, Michelle Arnal, Magalí \\ Cárdenas, and Juan C. Fernicola \\ Acta Palaeontologica Polonica 66 (1), 2021: 85-97 doi:https://doi.org/10.4202/app.00784.2020
}

In the last few years, the Quebrada de Los Colorados Formation has become an important middle Eocene fossiliferous unit in Northwestern Argentina. In this unit, the South American native ungulates were until now only represented by the order Notoungulata, including one family of Typotheria and three of Toxodontia. In this contribution, we present a new faunistic assemblage of South American native ungulates, collected from outcrops of the Quebrada de Los Colorados Formation at Los Cardones National Park, Calchaquí Valleys, Salta Province (Argentina). This new assemblage is constituted by the following taxa: litoptern Didolodontidae cf. Ernestokokenia sp., Astrapotheria indet., and notoungulate Notostylopidae Homalostylops sp., a ?Homalostylops sp., typothere "Oldfieldthomasiidae" Colbertia falui sp. nov., Colbertia lumbrerense, and Colbertia sp. and toxodont "Notohippidae" Pampahippus secundus. Colbertia falui sp. nov. differs from the other species of Colbertia by the following features: lower cheek teeth with both more labially angular and oblique trigonid; lower premolars more labio-lingually compressed; with proportionally larger trigonid, and shorter talonid; ectoflexid transversally deeper; lower molars with a more developed paralophid, and more expanded metalophid and entoconid; the latter is located in a more mesial position, being closer to the metaconid; deep and lingually narrower talonid basin; disto-lingual sulcus transversally shallower; more developed cingulids; and $\mathrm{m} 3$ with less lingually projected hypoconulid. This new fauna markedly increases the taxonomic richness known for this formation since it includes the first mention of notostylopids, "oldfieldthomasiids", litoptern didolodontids, and astrapotheres. With the current evidence, we postulate an ungulate migration from Patagonia to Northwestern Argentina during the Eocene. We also hypothesize that the observed taxonomic differences among the Quebrada de Los Colorados, Geste, and Lumbrera formations are more probably associated to orogenic factors that have regulated the faunal dynamic in Northwestern Argentina during the Paleogene than to a differential sampling effort or taphonomic biases.

Key words: Mammalia, South American native ungulates, Casamayoran SALMA, Paleogene, Quebrada de Los Colorados Formation, Argentina.

Mercedes Fernández [mechisfernandezpaleo@gmail.com ], Sección Paleontología 
de Vertebrados, Museo Argentino de Ciencias Naturales "Bernardino Rivadavia", Av. Ángel Gallardo 470, 1405 Ciudad Autónoma de Buenos Aires, Argentina;

Departamento de Ciencias Básicas, Universidad Nacional de Luján, Ruta 5 y Avenida Constitución 6700, Luján, Buenos Aires, Argentina; Consejo Nacional de Investigaciones Científicas y Tecnológicas (CONICET). Laura Chornogubsky [1 $\underline{\text { lchorno@macn.gov.ar }}$ ] and Magalí Cárdenas [magicacar7@gmail.com], Sección Paleontología de Vertebrados, Museo Argentino de Ciencias Naturales "Bernardino Rivadavia”, Av. Ángel Gallardo 470, 1405 Ciudad Autónoma de Buenos Aires, Argentina; Consejo Nacional de Investigaciones Científicas y Tecnológicas (CONICET). Ana N. Zimicz [natalia.zimicz@gmail.com], Instituto de Bio y Geociencias del Noroeste Argentino, Av. Bolivia 5550, 4400 Salta, Salta, Argentina; Consejo Nacional de Investigaciones Científicas y Tecnológicas (CONICET). Mariano Bond [constantino1453@yahoo.com.ar ] and Michelle Arnal [ michoarnal@fcnym.unlp.edu.ar], División Paleontología Vertebrados, Museo de La Plata, Facultad de Ciencias Naturales y Museo de La Plata, UNLP, Paseo del Bosque s/n, B1900FWA La Plata, Argentina; Consejo Nacional de Investigaciones Científicas y Tecnológicas (CONICET). Juan C.

Fernicola [jctano@yahoo.com], Departamento de Ciencias Básicas, Universidad Nacional de Luján, Ruta 5 y Avenida Constitución 6700, Luján, Buenos Aires, Argentina; Consejo Nacional de Investigaciones Científicas y Tecnológicas (CONICET).

This is an open-access article distributed under the terms of the Creative Commons Attribution License (for details please see creativecommons.org), which permits unrestricted use, distribution, and reproduction in any medium, provided the original author and source are credited.

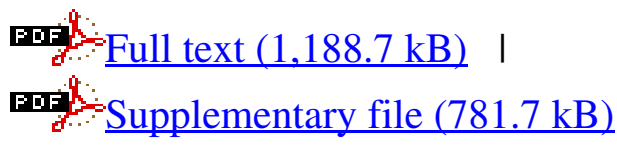

